\title{
PERKEMBANGAN EMBRIO DAN LARVA GURAMI (Osphronemus goramy Lac.) BASTAR, BLUESAFIR, DAN BULE
}

\section{EMBRYONIC AND LARVAL DEVELOPMENT OF BASTAR, BLUESAFIR, AND BULE OF GIANT GOURAMY (Osphronemus goramy Lac.)}

\author{
Dini W.K. Sari ${ }^{*}$, Ign. Hardaningsih ${ }^{*}$, dan Rustadi ${ }^{*}$
}

\begin{abstract}
The objectives of this research were to know the diameter and hatching rate of eggs, development rate of embryos, and survival rate of larvae of three subspecies of giant gouramy. Design experiment used in this study was completely randomized design (CRD). Eggs were incubated at $29^{\circ} \mathrm{C}$ and larvae were reared at the same temperature until post larvae stage (most of the yolk sac completely absorbed).

The results showed that there was no significant difference among subspecies ( $\alpha=5 \%$ ). The average diameter of the eggs were 2.61, 2.47, and $2.39 \mathrm{~mm}$ for bule, bastar, and bluesafir, respectively. The highest hatching rate was reached by eggs of bluesafir, followed by bastar and bule. In addition, survival rates of larvae were $93.80 \%, 91.60 \%$, and $84.20 \%$ for bule, bastar, and bluesafir, respectively. The highest specific length growth rate reached by bluesafir ( $7.4 \%$ per day) followed by bastar $(6.80 \%$ per day) and bule $(5.72 \%$ per day). The highest specific weight growth rate was reached by bule $(6.85 \%$ per day) followed by bluesafir (6.65\% per day) and bastar (5.37\% per day).
\end{abstract}

\section{Key words : Bastar, Bluesafir, Bule, Osphronemus goramy Lac., embryo, larvae}

\section{Pengantar}

Gurami (Osphronemus goramy Lac.) merupakan salah satu jenis ikan air tawar yang mempunyai nilai ekonomis tinggi karena harganya yang baik dan relatif stabil di pasaran. Gurami merupakan ikan yang lezat, mengandung gizi yang tinggi, tekstur dagingnya tidak lembek, duri dan tulangnya sedikit, sehingga banyak diminati masyarakat.

Soewardi dkk. (1995) mengelompokkan gurami yang berasal dari Parung (Bogor) ke dalam lima subspesies berdasarkan karakter warna, bentuk kepala, bentuk tubuh, dan pola sisik. Lima subspesies tersebut adalah gurami bule, bluesafir, paris, bastar, dan batu. Subspesies-subspesies tersebut belum diketahui karakteristiknya terutama mengenai perkembangan embrio dan larvanya.
Proses-proses yang terdapat dalam perkembangan awal hidup ikan berhubungan erat dengan stabilitas populasi ikan tersebut dalam suatu perairan. Awal perkembangan hidup ikan mempunyai andil besar dalam menentukan variasi produksi tiap-tiap tahunnya (Effendie, 1997). Interaksi antara faktor genetik dan lingkungan mempengaruhi proses perkembangan embrio dan juga menentukan berbagai macam karakteristik individu (Lagler et al., 1977). Penelitian ini bertujuan untuk mengetahui diameter telur, daya tetas telur, waktu penetasan telur, dan waktu perkembangan embrio; serta laju pertumbuhan dan laju sintasan larva gurami bastar,bluesafir, dan bule.

\section{Bahan dan Metode}

Metode yang digunakan dalam penelitian ini adalah metode eksperimen menggunakan rancangan acak lengkap (RAL).

\footnotetext{
") Jurusan Perikanan Fakultas Pertanian UGM, JI. Flora Gedung A4, Bulaksumur, Yogyakarta 55281
} 
Perlakuan terdiri atas tiga ulangan dari tiga pasang induk yang berbeda. Macam perlakuan yang digunakan dalam penelitian ini adalah: P1 (telur dan larva gurami bastar), P2 (telur dan larva gurami bluesafir), P3 (telur dan larva gurami bule).

Telur diambil dari kolam pemijahan bersama dengan sarangnya segera setelah pemijahan berlangsung. Selanjutnya sarang diuraikan dalam bak-bak berisi air sampai telur-telur gurami lepas dari sarangnya. Kelompok telur yang dipilih adalah telur yang berwarna kuning mengkilat. Telur sebelum dimasukkan ke dalam inkubator direndam terlebih dahulu dalam larutan Methylen blue 3 ppm selama 10 menit. Inkubator yang digunakan dalam penelitian ini berupa akuarium kaca berukuran $45 \times 30 \times 30 \mathrm{~cm}^{3}$ yang disekat menjadi 4 bagian dengan kapasitas masing-masing 10,125 I. Telur yang ditebarkan pada tiap inkubator sebanyak 100 butir. Sebelum telur ditebar, suhu diatur sesuai perlakuan. Suhu air dalam penetasan ini adalah konstan dan sama tiap perlakuan, yaitu $29 \pm 1^{\circ} \mathrm{C}$ (Widijastuti, 1995).

Telur diukur diameternya, selanjutnya perkembangan embrio diamati di bawah mikroskop menggunakan cawan porselen berisi air. Tahap-tahap perkembangan embrio dicatat hingga menetas. Telur yang mati, berwarna kuning keruh, segera dibuang, dan telur yang menetas dihitung daya tetasnya. Telur yang tidak menetas, cangkang telur dan kotoran lain yang ada di dasar akuarium dibuang dengan cara disipon. Setelah telur menetas, larva dipelihara sampai larva mampu mengambil makanan. Larva diamati perkembangannya dengan mengukur berat dan panjang larva setelah telur menetas (prolarva), dan larva setelah mampu mengambil makanan dari lingkungannya (postlarva). Waktu postlarva dapat diketahui dengan cara memberikan pakan berupa Tubifex sp. pada 10\% sampel larva. Apabila, sudah lebih dari 50\% larva memakan pakan tersebut, ditandai dengan terlihatnya pakan pada lambung yang masih terlihat transparan, maka dilakukan pengukuran panjang dan berat larva yang masih dipelihara dalam inkubator (belum diberi pakan) sebanyak $5 \%$ dari populasi awal tebar, dan dihitung kelulushidupannya. Pengukuran diameter telur, panjang dan berat larva, dengan mengambil sampel sebanyak $5 \%$ dari populasi.

\section{Pengumpulan data}

a. Diameter telur, diukur dengan menggunakan mikrometer dalam kondisi butir minyak berada di atas.

b. Tahap-tahap dan kecepatan perkembangan embrio, diamati di bawah mikroskop selama waktu-waktu tertentu dan dicatat setiap terjadi perubahan fase sampai menetas. Waktu penetasan diukur mulai fase pembelahan sel sampai telur menetas.

c. Jumlah telur yang menetas dihitung, selanjutnya daya tetas telur (\%) dihitung dengan membandingkan antara jumlah telur yang menetas dengan jumlah telur yang ditebarkan di tiap inkubator dikalikan $100 \%$.

d. Pengamatan larva dilakukan sejak telur menetas (prolarva) hingga larva mampu mengambil makanan dari lingkungannya (postlarva), dengan melihat panjang dan berat larva, serta waktu yang dibutuhkan larva setelah telur menetas sampai postlarva. Laju pertumbuhan spesifik, diukur dengan menggunakan persamaan :

$$
\mathrm{G}=\frac{(\ln \mathrm{YT}-\ln \mathrm{Yt})}{\mathrm{T}-\mathrm{t}} \times 100 \%
$$

(Weatherley, 1972)

keterangan :

$\mathrm{G}=$ laju pertumbuhan spesifik

$\mathrm{YT}=$ panjang/berat akhir (pada waktu $\mathrm{t}$ )

$\mathrm{Yt}=$ panjang/berat awal

e. Jumlah larva setelah telur menetas dan yang hidup pada akhir percobaan dihitung untuk mengetahui laju sintasan (survival rate/SR). Laju sintasan dihitung menggunakan rumus : 


$$
\begin{aligned}
& \mathrm{S}=\frac{\mathrm{N}_{\mathrm{t}}}{\mathrm{N}_{\mathrm{o}}} \times 100 \% \quad \text { (Effendie, 1979) } \\
& \text { keterangan : } \\
& \begin{aligned}
\mathrm{S} \quad=\text { laju sintasan larva } \\
\mathrm{Nt} \quad=\text { jumlah ikan (larva) yang } \\
\text { hidup pada akhir periode }
\end{aligned} \\
& \mathrm{No}=\text { jumlah ikan (larva) yang } \\
& \text { hidup pada. awal periode }
\end{aligned}
$$

\section{Analisis data}

Pengaruh subspesies gurami yang berbeda terhadap ukuran diameter dan daya tetas telur, dan waktu penetasan telur; serta. perkembangan dan laju sintasan larva dianalisis menggunakan analisis sidik ragam (anova) dengan tingkat kepercayaan 95\%. Data perkembangan embrio dan kualitas air selama penelitian dianalisis secara deskriptif.

\section{Hasil dan Pembahasan}

Hasil analisis terhadap diameter telur, waktu penetasan, dan daya tetas telur; serta pertumbuhan, perkembangan, dan laju sintasan larva gurami bastar, bluesafir, dan bule tidak menunjukkan adanya perbedaan yang nyata pada tingkat kepercayaan 95\%. Hal ini menunjukkan bahwa pada awal perkembangan hidup gurami, baik ukuran telur, larva, maupun pertumbuhannya masih relatif sama. Perbedaan karakter antar subspesies gurami tersebut mungkin akan terlihat jelas pada tingkat kehidupan yang lebih lanjut, ataupun dengan melihat perbedaannya sampai tingkat DNA. Meskipun demikian, hasil penelitian menunjukkan adanya kecenderungan perbedaan karakter gurami bastar, bluesafir, dan bule pada tingkat embrio dan larva.

Telur gurami bule dengan rerata diameter terbesar $(2,61 \mathrm{~mm})$ menetas dengan rerata waktu penetasan paling cepat (40.01') dibanding kedua subspesies lainnya. Akan tetapi rerata waktu penetasan telur gurami bule tidak terpaut jauh, dengan rerata waktu penetasan telur gurami bluesafir (40.19') yang memiliki

\begin{tabular}{|c|c|c|c|c|}
\hline No & Parameter & P1 (Bastar) & P2 (Bluesafir) & P3 (Bule) \\
\hline 1 & Diameter telur $(\mathrm{mm})$ & $2,47 \pm 0,16^{\text {ns }}$ & $2,39 \pm 0,03^{\text {ns }}$ & $2,61 \pm 0,08^{\text {ns }}$ \\
\hline \multirow[t]{11}{*}{2} & Perkembangan embrio (jam/mnt ke-) & & & \\
\hline & $1 \mathrm{sel}$ & 0 & 0 & 0 \\
\hline & $2 \mathrm{sel}$ & $0 / 27$ & $0 / 25$ & $0 / 20$ \\
\hline & $4 \mathrm{sel}$ & $0 / 49$ & $0 / 51$ & $0 / 45$ \\
\hline & $8 \mathrm{sel}$ & $1 / 26$ & $1 / 14$ & $1 / 07$ \\
\hline & $16 \mathrm{sel}$ & $2 / 22$ & $1 / 48$ & $1 / 45$ \\
\hline & $32 \mathrm{sel}$ & $2 / 55$ & $2 / 23$ & 2/44 \\
\hline & Blastula & $3 / 34$ & $2 / 52$ & $3 / 23$ \\
\hline & Gastrula & $12 / 02$ & $12 / 27$ & $11 / 17$ \\
\hline & Perkembangan calon organ tubuh & $23 / 05$ & 22/37 & $21 / 14$ \\
\hline & Penetasan & $44 / 02$ & $40 / 12$ & $40 / 01$ \\
\hline 3 & Waktu penetasan telur (jam) & $44,04 \pm 3,58$, ns & $40,19 \pm 6,26$, ns & $40.01 \pm 0,92$, ns \\
\hline 4 & Daya tetas (\%) & $90,00 \pm 5,00^{\mathrm{ns}}$ & $95,33 \pm 1,53^{\text {ns }}$ & $88,00 \pm 11,27^{\mathrm{ns}}$ \\
\hline 5 & Panjang prolarva $(\mathrm{mm})$ & $5,29 \pm 0,28^{\mathrm{ns}}$ & $4,76 \pm 0,38^{\mathrm{ns}}$ & $5,46 \pm 0,34{ }^{\mathrm{ns}}$ \\
\hline 6 & Berat prolarva (mg) & $5,56 \pm 0,69^{\text {ns }}$ & $4,69 \pm 0,566^{n s}$ & $5,19 \pm 0,63^{\mathrm{ns}}$ \\
\hline 7 & Panjang postlarva (mm) & $9,64 \pm 0,51^{\mathrm{ns}}$ & $9,37 \pm 0,08^{\mathrm{ns}}$ & $9,60 \pm 0,31^{\text {ns }}$ \\
\hline 8 & Berat postlarva & $9,46 \pm 3,26^{\text {ns }}$ & $8,77 \pm 1,46^{\mathrm{ns}}$ & $10,27 \pm 0,64^{\mathrm{ns}}$ \\
\hline 9 & Laju pertumbuhan panjang spesifik (\%/hari) & $6,44 \pm 0,38^{\mathrm{ns}}$ & $7,27 \pm 0,41^{\mathrm{ns}}$ & $5,65 \pm 0,47^{\mathrm{ns}}$ \\
\hline 10 & Laju pertumbuhan berat spesifik (\%/hari) & $5,37 \pm 3,022^{n s}$ & $6,65 \pm 2,28^{\mathrm{ns}}$ & $6,85 \pm 1,03^{\text {ns }}$ \\
\hline 11 & Laju sintasan larva (\%) & $91,6 \pm 9,25^{\mathrm{ns}}$ & $84,2 \pm 7,77^{\text {ns }}$ & $93,8 \pm 1,85^{\mathrm{ns}}$ \\
\hline 12 & Waktu postlarva & $9,33 \pm 0,58^{\text {ns }}$ & $9,33 \pm 0,58^{\text {ns }}$ & $10 \pm 0^{\text {ns }}$ \\
\hline
\end{tabular}
rerata diameter telur terkecil $(2,39 \mathrm{~mm})$. Telur gurami bastar dengan rerata diameter telur $2,47 \mathrm{~mm}$ menetas lebih lama (44.04') dibanding dua subspesies lainnya.

Tabel 1. Perbandingan embrio dan larva gurami Bastar, Bluesafir, dan Bule

Keterangan : ns = tidak berbeda nyata pada tingkat kepercayaan $95 \%$ 
Energi yang digunakan untuk metabolisme maupun perkembangan embrio pada telur berasal dari yolk sac, maupun partikel-partikel terlarut dalam air yang diduga juga diserap oleh telur (Lagler et al., 1977, Blaxter, 1979). Waktu penetasan telur gurami bastar yang relatif lama ini dapat dimanfaatkan untuk perkembangan optimal embrio dalam memanfaatkan yolk sac maupun partikel-partikel terlarut dari lingkungannya, yang nantinya terekspresi dari berat larva gurami bastar setelah telur menetas, yaitu lebih berat dibanding subspesies bule maupun bluesafir.

Telur ketiga subspesies gurami yang ditetaskan pada suhu $29^{\circ} \mathrm{C}$ membutuhkan waktu penetasan dengan kisaran 33.05'-46.21'. Penetasan ini berjalan lebih cepat dibandingkan dengan penetasan telur gurami yang dilakukan pada suhu $28^{\circ} \mathrm{C}$ yang membutuhkan waktu 48 jam (Woynarovich dan Horvath (1980) cit Hardaningsih dan Triyanto 1993). Suhu yang lebih tinggi menyebabkan laju metabolisme berlangsung lebih cepat sehingga penetasan juga berlangsung lebih cepat.

Rerata derajat penetasan telur/Hatching Rate (HR) selama penelitian relatif tinggi, yaitu $90 \%$, 95,33\%, dan $88 \%$, masingmasing untuk gurami bastar, bluesafir, dan bule. HR yang cukup tinggi ini disebabkan adanya perlakuan lingkungan yang diatur sedemikian rupa dengan suhu relatif stabil pada $29 \pm 1^{\circ} \mathrm{C}$, adanya aerasi, pergantian air, penyiponan, serta pengambilan telur dari induk yang dipijahkan di tempat yang sama dengan lokasi penelitian, sehingga telur tidak perlu mengalami guncangan selama pengangkutan.

Menurut Lagler et al. (1977), telur ikan laut sangat sensitif sampai gastrulasi berakhir. Telur yang rentan ini mungkin karena proses morfogenesis yang sensitif (Blaxter, 1979) dan awal terbentuknya sistem saraf sentral (New, 1966). Mortalitas telur yang tinggi dapat juga terjadi pada telur ikan gurami, sehingga pada fase ini penanganan terhadap telur harus hati-hati, maka faktor lingkungan harus mendukung agar mortalitas telur dapat ditekan.

Prolarva setelah telur menetas terlihat transparan dan berenang dengan posisi terbalik karena membawa cadangan makanan berupa kuning telur dan butir minyak. Sirip dada dan ekor sudah ada tetapi belum sempurna bentuknya dan kadang-kadang sudah digerakkan, sirip punggung dan sirip perut juga belum sempurna. Mulut dan rahang belum berkembang dan ususnya masih berupa tabung lurus, sistem peredaran darahnya belum sempurna (Effendie, 1997).

Gurami bluesafir dengan rerata diameter telur terkecil menghasilkan prolarva dengan rerata panjang dan berat yang lebih kecil dibanding bastar dan bule. Gurami bule dengan rerata diameter telur terbesar menghasilkan prolarva dengan rerata panjang prolarva, paling besar $(5,46 \mathrm{~mm})$, sedangkan bastar dengan rerata diameter telur lebih kecil dibanding bule memiliki rerata berat prolarva, setelah menetas tertinggi yaitu $5,56 \mathrm{mg}$. Diduga tingginya berat prolarva gurami bastar ini disebabkan gurami bastar lebih efektif menggunakan energi dari dalam telur untuk pertumbuhan embrio yang nantinya menjadi larva, sementara, gurami bule menghabiskan lebih banyak energi untuk proses penetasan yang cepat.

Perkembangan larva lebih lanjut, yaitu ketika kuning telur hampir terserap habis dan larva mulai mencari makanan dari lingkungannya (postlarva), mulut bersiap berfungsi, usus dan mata berkembang lebih cepat, dan larva mulai mengambil makanan dari luar. Operculum dan sirip dada sudah aktif, dan larva pada umumnya sudah berenang di permukaan air tetapi akan berenang ke dasar akuarium jika merasa terganggu, serta sirip dada mulai bergerak konstan (New, 1966). Masing-masing subspesies gurami sampai tahap postlarva menunjukkan pertambahan panjang dan berat. Postlarva bluesafir memiliki ukuran panjang 
dan berat lebih kecil dibanding bastar dan bule; meskipun demikian laju pertumbuhan panjang spesifiknya paling tinggi, yaitu $7,27 \%$ /hari. Hal ini menunjukkan bahwa pertumbuhan larva gurami bluesafir prolarva. sampai postlarva cenderung memanjang dibandingkan kedua subspesies lainnya. Laju pertumbuhan panjang spesifik gurami bule paling rendah (5,65\%/hari), akan tetapi memiliki laju pertumbuhan berat spesifik tertinggi, yaitu sebesar $6,85 \% /$ hari. Tingginya laju pertumbuhan berat spesifik ini diduga karena gurami bule lebih efektif menggunakan energi dari yolk sac untuk pertumbuhan berat larva. Gurami bule memiliki postlarva dengan rerata berat tertinggi dibanding gurami bastar dan bluesafir. Rerata, panjang postlarva, gurami bule masih lebih kecil dibanding bastar, akan tetapi tidak terpaut jauh dengan bule dan bastar masing-masing sebesar 9,6 $\mathrm{mm}$ dan 9,64 $\mathrm{mm}$, membutuhkan waktu sembilan sampai sepuluh hari menjadi postlarva. Larva gurami bastar dan bluesafir membutuhkan waktu rata-rata 9,33 hari untuk sampai postlarva. Gurami bule, membutuhkan waktu rata-rata 10 hari. Rerata waktu untuk sampai postlarva gurami bule paling lama dibanding kedua subspesies lainnya, karena gurami bule mempunyai rerata, diameter telur yang paling besar, sehingga larva mempunyai lebih banyak cadangan makanan dalam tubuhnya yang dapat digunakan untuk periode yang lebih lama sampai larva mulai makan dari luar.

Terserapnya kuning telur seiring dengan tumbuhnya larva memungkinkan larva dapat mempertahankan dari dalam posisi berenang, yang biasanya menjadi petunjuk kapan benih mulai dapat diberi pakan (Piper et al.,1982). Pakan sebaiknya sudah tersedia ketika larva mulai makan dari lingkungan (postlarva) karena apabila saat awal pemberian pakan ini terlambat, yaitu jauh setelah persediaan kuning telur pada tubuh larva habis terserap, benih akan kelaparan dan terlampau lemah untuk makan walaupun pakan alami diberikan pada larva tersebut (Piper et al., 1982).
Rerata laju sintasan gurami bule menunjukkan angka tertinggi yaitu $93,88 \%$, dibanding bastar $91,6 \%$ dan bluesafir 84,2\%. Kirpicnikov (1970) cit Tridjoko (1996) menyatakan bahwa telur yang berukuran besar juga menghasilkan larva berukuran besar, pertumbuhan yang cepat, dan laju sintasan yang tinggi

Gurami bluesafir, meskipun mempunyai daya tetas telur yang tinggi $(95,33 \%)$, menghasilkan larva dengan laju sintasan paling rendah $(84,2 \%)$ dibanding dua subspesies lainnnya. Hal ini disebabkan larva hasil tetasan gurami bluesafir relatif lebih tidak tahan terhadap perubahan lingkungan barunya, yaitu embrio yang semula dilindungi lapisan perivitelin dan membran telur, menjadi larva yang hidup bebas di perairan, yang harus mengalami metabolisme tubuh seperti respirasi dan ekskresi menggunakan organ-organ tubuhnya sendiri. Larva juga harus memelihara keseimbangan osmotik tanpa bantuan membran telur (Royce, 1984).

\section{Kesimpulan dan Saran}

\section{Kesimpulan}

1. Diameter, waktu penetasan, dan daya tetas telur; perkembangan, dan laju sintasan larva gurami bastar, bluesafir dan bule menunjukkan kesamaan antar 3 subspesies tersebut.

2. Gurami bule dengan diameter telur terbesar menghasilkan larva dengan ukuran paling besar, laju pertumbuhan berat spesifik larva terbesar, dan laju sintasan larva tertinggi.

\section{Saran}

1. Perlunya penelitian mengenai fase perkembangan lebih lanjut gurami bastar, bluesafir, dan bule serta penelusuran karakter ketiganya sampai tingkat DNA.

2. Perlu penelitian perkembangan embrio dan larva pada subspesies gurami lainnya, yaitu subspesies paris dan batu. 


\section{Daftar Pustaka}

Blaxter, J.H.S. 1979. Development eggs and larvae. In Fish Physiology. Hoar W.S., D.J. Randall, and J.R. Brett (eds). Academic Press. New York. Vol. 3: 177-251.

Effendie, M.I. 1979. Metode biologi perikanan. Yayasan Dewi Sri. Bogor. 112p.
-1997. Biologi perikanan. Yayasan Pustaka Nusantara. Yogyakarta.163p.

Hardaningsih, Ign. dan Triyanto. 1993. Penggunaan malachyte green dan kalium permanganat pada penetasan telur gurami (Osphronemus goramy Lac.). Fakultas Pertanian UGM. Yogyakarta.

Lagler, K.F., J.E. Bardach, R.R. Miller, and M. Passino. 1977. Ichthyology. John Wiley and Sons. New york. 506p.

New, D.A.T. 1966. The culture of vertebrate embryos. Logos PressAcademic Press. London: 187-220.

Piper, R.G., I.B. McElwain, L.E. Orme, J.P. McCraren, L.G. Fowler, and J.R. Leonard. 1982. Fish hatchery management. US Dept. of The
Interior, Fish, and Wildlife Service. Washington DC.517p.

Royce, W.F. 1984. Introduction to the practice of fishery science. Academic Press. Orlando.428p

Soewardi, K., R. Rachmawaty, R. Affandi, dan D.G. Bengen. 1995. Penelusuran varietas ikan gurame (Osphronemus goramy Lac.) berdasarkan penampilan karakter luar (fenotip). J. IImu-IImu Perairan dan Perikanan Indonesia. 3(2):2331.

Tridjoko, B. Slamet, D. Makatutu, dan K. Sugama. 1996. Pengamatan pemijahan dan perkembangan telur kerapu bebek (Cromileptes altivelis) pada bak secara terkontrol. J. Penelitian Perikanan Indonesia. 2(2): 55-62.

Weatherley, A.H. 1972. Fish and invertebrate culture: water management in closed system. Wiley Interscience. New York. 145p.

Widijastuti,I. 1995. Suhu air, pengaruhnya terhadap perkembangan embrio dan daya tetas telur gurami (Osphronemus goramy Lac.). Fakultas Pertanian UGM. Yogyakarta. 